\title{
Kinetics and Equilibrium of Mercury Sorption by Three Different Types of Live Algae
}

\author{
Andréa Ryba ${ }^{1^{*}}$ \\ https://orcid.org/0000-0001-7257-9611 \\ Everton Fernando Zanoelo 2 \\ https://orcid.org/0000-0001-9347-4026 \\ Marcelo Kaminski Lenzi ${ }^{2}$ \\ https://orcid.org/0000-0002-0103-9017
}

${ }^{1}$ Federal University of Paraná, Department of Transportation, Curitiba, PR, Brazil. ${ }^{2}$ Federal University of Paraná, Department of Chemical Engineering, Curitiba, PR, Brazil.

Received: 2019.02.15; Accepted: 2020.02.13.

* Correspondence: andrea.ryba@ufpr.br

\section{HIGHLIGHTS}

- Solid phase: the pseudo-first order model with constant area presents $R^{2}=0.97$.

- Liquid phase: the pseudo-first order model with variable area best fit the data.

- The Redlich-Peterson isotherm best describes the equilibrium.

\begin{abstract}
The kinetics and equilibrium of experimental data of mercury (II) sorption using three different macrophytes E. crassipes, E. azurea and S. ariculata were analyzed. From the kinetic models used, the model 1, which considers the surface area of constant sorption, presents the coefficient of determination, $R^{2}$, closer to the unit (0.97). Already, in the liquid phase, the best fit of the experimental data was obtained for model $2\left(R^{2}=0.96\right)$, which considers the variable surface area. The calculated values for the determination coefficients indicate that the Redlich-Peterson isotherm best describes the equilibrium $\left(R^{2}=0.79\right)$. The results show that the macrophyte $S$. ariculata surface area, which presented the highest adsorption potential $\left(15.77 \times 10^{-4} \mathrm{~m}^{2} . \mathrm{g}^{-1}\right)$, was far below those found in the best adsorbents. However, considering the large volume of adsorbent material required in an industrial plant and the low cost of the analyzed adsorbents, it is considered that the macrophytes investigated have a considerable potential for the removal of mercury from wastewater.
\end{abstract}

Keywords: Sorption, Mercury, Heavy Metal, Equilibrium, Kinetic.

\section{INTRODUCTION}

The growth industrial activity in global scale and, consequently, the generation of effluents with high contamination potential are leading to a considerable increase in levels of not only environmental pollution, but also ecosystems deterioration. Among these pollutants, heavy metals such as lead, cadmium, mercury, chromium, nickel, and others present in surface and groundwater [1] stand out. These contaminants include Mercury (II), generally considered to be one of the most toxic to the human health, the environment and other organisms living in the contaminated environment $[2,3]$. Although it isn't a biodegradable contaminant, there 
is a particular concern about it because of its bioaccumulation features, which can cause neurological and renal disorders, as well as deterioration of lung functions in humans [4-6].

Due to the highly toxic characteristics presented by heavy metals in general, many techniques of removal and recovery of them have been suggested. The most commonly used methods include precipitation/coagulation, reduction and membrane separation [7,1]. However, many of these conventional operations have either technical or economic limitations, especially when dealing with lower levels of contamination.

In this context, alternative methods have been proposed for recovery of metal ions and minimization of waste generation. Biosorption using algae as an adsorbent has shown to be an alternative tool of great potential in the removal and recovery of heavy metals from aqueous solutions. This technique dates to 1970s, when radioactive elements were found in algae [1]. It is based, then, on the binding capacity between the metal and the adsorbent, the latter being alive or dead microorganisms [8], biomass [9,1], bacteria [10], fungi [11], algae [7,12-14] or algae as a potential carbon source [15]. Among these biomaterials, the algae have attracted special interest due to their abundance, low cost, considerable efficiency and the possibility of recovery of the metal. Focusing on a more comprehensive knowledge of the process, suitable mathematical models of both kinetics and equilibrium would play a fundamental role.

The objective of this study was to develop mathematical models aimed to describe both the sorption kinetics and equilibrium of removal of mercury (II) from liquid effluents. The evaluated bioadsorbents were freshwater aquatic macrophytes such as Eichhornia crassipes (Mart.) Solms., Eichhornia azurea and Salvinia ariculata. A set of three kinetic models was suggested based on mass balances on mercury in the solid and liquid phases. The rates of adsorption were of first, and second order with respect to the difference between the concentration for a given time and the one at equilibrium. To define accurately the adsorption order and rate constant is an essential prerequisite to the design of adsorption equipment by involving an adsorbent. The representation of experimental data on mercury sorption equilibrium with aquatic plants, involving classical adsorption isotherms is another important objective of this investigation, since it provides considerable knowledge regarding the interaction between the mercury and the algae used. Thus, different isothermal models will be investigated, such as Langmuir, Langmuir-Freundlich, Henderson and RedlichPeterson.

\section{MATERIAL AND METHODS}

\section{Reference Experiments}

For the realization of this theoretical investigation, the adsorption of $\mathrm{Hg}$ (mercury) ions using aquatic macrophytes, more specifically those from freshwater, was used the experimental data presented by Rodrigues [16]. His work was based on the study reported by Muramoto and Oki [17], whose evaluated species was also the object of study by Rodrigues et al. [18], where further details regarding the experimental procedure can be found.

To summarize, the present study considered only the reported data based on Eichhornia crassipes, Eichhornia azurea and Salvinia ariculata. Adult macrophytes were collected close to the Paraná river, in the region of Porto Rico, located in the state of Paraná, Brazil $(-22.76,-53.26)$. Due to the need to keep the plants alive for the experiments and to promote the development and adaptation of the species to the new environment, they were maintained for six days in nutrient solution, prepared with Hoagland and Arnon diluted 1:50. This solution provides the maintenance of the $\mathrm{pH}$ close to neutrality, since it favors the ionic exchanges with the plants. Polypropylene containers of capacity of 17 liters were used to carry out the batch experimental runs. In order to keep the conditions of temperature and humidity controlled, the experiments were conducted in the greenhouse, located on the campus of the State University of Maringá (UEM). Once the temperature $\left(25 \pm 3^{\circ} \mathrm{C}\right)$ and relative humidity $(89 \pm 3 \%)$ were set for the full development of plant species, a static system involving the algae was simulated. The experiments were conducted with two injections of $\mathrm{Hg}$ (II) at the nominal concentrations of 500, 1000 and $2000 \mathrm{ppb}$. The second injection of mercury was performed only after an interval of 120 hours, counted from the first injection. Algae and solution samples were obtained at $24,48,96,120,144,168$ and 216 hours in order to experimentally determine the concentrations of the heavy metal in the solid and liquid phases. 


\section{Analytical Determination}

Samples containing roots, stem and macrophytic leaves were submitted to drying, milling and subsequent destruction of organic matter [18]. This last stage of treatment of the samples occurred by wet method, as described by Gorsuch [19] and recommended by Analytical Methods Committee [20]. The analysis of the treated samples occurred through atomic absorption spectrophotometry, followed by a mercury vapor generator (EAA-SGVM). The aliquots of solution removed from the vessel containing water, mercury and macrophytes were pretreated with concentrated nitric acid for storage purposes. Afterwards, they underwent digestion, described in detail by Omang [21], and referred to the spectrophotometer.

\section{Mathematical Modeling of the Kinetics of the Process}

The adsorption kinetics expresses the rate of removal of solute from the aqueous solution by the adsorbent used. This relationship can be obtained by means of a material balance in the solid phase of the adsorption bed containing water, mercury and the biosorbent. Thus, due to the need to understand the mechanisms of adsorption and verification of eventual limitations, three different kinetic models were proposed in this investigation. All of them involve an apparent coefficient, which theoretically is a combination of transport resistance and solute adsorption by macrophytes. models 1 and 2 are of pseudo-first order, widely reported in the literature, but the first one assumes a constant area of adsorption, while in the second the area is considered variable. On the other hand, the empirical model 3 considers that the rate of adsorption is proportional to the squared difference between the pollutant concentration at equilibrium and at a given instant of time $(\mathrm{t})$. The mathematical models have a global coefficient, which theoretically represents a combination of transport resistances (diffusive and convective) and adsorption of mercury.

\section{Constant surface area model - model 1}

The Lagergren model [22] of pseudo first order assumes a constant area of adsorption, whose equation, based on the adsorption capacity of the solid, after being adapted to the nomenclature of this study, is given by:

$$
\frac{\mathrm{dC}_{\mathrm{s}}}{\mathrm{dt}}=-\mathrm{k}_{1} \cdot\left(\mathrm{C}_{\mathrm{s}}-\mathrm{C}_{\mathrm{se}}\right)
$$

where $\mathrm{C}_{\mathrm{s}}$ and $\mathrm{C}_{\mathrm{se}}$ represent the concentration of the pollutant in algae at time $\mathrm{t}(\mathrm{s})$ and equilibrium, respectively, given in ppm (parts per million) and $k_{1}$ is the global coefficient (1/s), parameter of the model given by the product of the transport coefficient by constant adsorption area (1/s).

For the liquid the equation is given by:

$$
\frac{\mathrm{dC}_{1}}{\mathrm{dt}}=-\alpha \cdot \frac{\mathrm{dC}_{\mathrm{s}}}{\mathrm{dt}}=\alpha \cdot \mathrm{k}_{1} \cdot\left(\mathrm{C}_{\mathrm{s}}-\mathrm{C}_{\mathrm{se}}\right)
$$

where the concentration of $\mathrm{Hg}$ in the solution is $\mathrm{C}_{l}$ and $\alpha$ is the ratio of the mass of dry adsorbent and mass of liquid ( $\mathrm{g}$ of adsorbent / $\mathrm{g}$ solution).

The ordinary differential equations 1 and 2 can be analytically solved, by integrating from $t=t_{i}$, with $C_{\mid}=C_{l i}$ and $\mathrm{C}_{\mathrm{s}}=\mathrm{C}_{\mathrm{si}}$ to $\mathrm{t}=\mathrm{t}$, with $\mathrm{C}_{l}(\mathrm{t})$ and $\mathrm{C}_{\mathrm{s}}(\mathrm{t})$, yielding the following equations:

$$
\begin{gathered}
\mathrm{C}_{\mathrm{s}}(\mathrm{t})=\mathrm{C}_{\mathrm{se}}-\left(\mathrm{C}_{\mathrm{se}}-\mathrm{C}_{\mathrm{si}}\right) \cdot \mathrm{e}^{-\mathrm{k}_{1} \cdot\left(\mathrm{t}-\mathrm{t}_{\mathrm{i}}\right)} \\
\mathrm{C}_{1}(\mathrm{t})=\mathrm{C}_{\mathrm{li}}+\alpha \cdot\left(\mathrm{C}_{\mathrm{se}}-\mathrm{C}_{\mathrm{si}}\right) \cdot\left(\mathrm{e}^{-\mathrm{k}_{1} \cdot\left(\mathrm{t}-\mathrm{t}_{\mathrm{i}}\right)}-1\right)
\end{gathered}
$$

where, $\mathrm{C}_{\mathrm{si}}$ represent the concentration of the pollutant in algae and $\mathrm{C}_{\mathrm{li}}$ the initial concentration of the mercury in solution.

\section{Variable surface area model - model 2}

The second modeling approach derives from a phenomenological interpretation of the empirical model of Muramoto and Oki [17], which is represented by the following ordinary differential equation: 


$$
\frac{\mathrm{dC}_{\mathrm{s}}}{\mathrm{dt}}=\mathrm{k}_{2} \cdot \mathrm{C}_{\mathrm{s}} \cdot\left(1-\frac{\mathrm{C}_{\mathrm{s}}}{\mathrm{C}_{\mathrm{se}}}\right)
$$

A simple algebraic manipulation of Equation 5 leads to Equation 6:

$$
\frac{\mathrm{dC}_{\mathrm{s}}}{\mathrm{dt}}=-\mathrm{k}_{2} \cdot \frac{\mathrm{C}_{\mathrm{s}}}{\mathrm{C}_{\mathrm{se}}} \cdot\left(\mathrm{C}_{\mathrm{s}}-\mathrm{C}_{\mathrm{se}}\right)
$$

Since the experimental results obtained by Rodrigues et al. [18] indicate that the increase in the adsorption time leads to a logarithmic growth of the ratio between $\mathrm{C}_{\mathrm{s}}$ and $\mathrm{C}_{\mathrm{se}}$, then it can be assumed that the Muramoto and Oki [17] is a pseudo-first-order model with logarithmic variation of the surface area and is given by Equation 7:

$$
\frac{\mathrm{dC}_{\mathrm{s}}}{\mathrm{dt}}=-\mathrm{k}_{2} \cdot\left(\mathrm{k}_{3} \cdot \ln (\mathrm{t})+\mathrm{k}_{4}\right) \cdot\left(\mathrm{C}_{\mathrm{s}}-\mathrm{C}_{\mathrm{se}}\right)
$$

the equation of the rate of change of the $\mathrm{Hg}$ concentration in the liquid phase being readily obtained:

$$
\frac{\mathrm{dC}_{1}}{\mathrm{dt}}=-\alpha \cdot \frac{\mathrm{dC}_{\mathrm{s}}}{\mathrm{dt}}=\alpha \cdot \mathrm{k}_{2} \cdot\left(\mathrm{k}_{3} \cdot \ln (\mathrm{t})+\mathrm{k}_{4}\right) \cdot\left(\mathrm{C}_{\mathrm{s}}-\mathrm{C}_{\mathrm{se}}\right)
$$

The equations 7 and 8 constitute a system of ordinary differential equations, which can also be analytically solved, resulting in the following expressions:

$$
\begin{gathered}
\mathrm{C}_{\mathrm{s}}(\mathrm{t})=\mathrm{C}_{\mathrm{se}}-\left(\mathrm{C}_{\mathrm{se}}-\mathrm{C}_{\mathrm{si}}\right) \cdot \mathrm{e}^{\left(\mathrm{k}_{2} \cdot\left[-\mathrm{k}_{3} \cdot \mathrm{t} \cdot \ln (\mathrm{t})+\mathrm{k}_{3} \cdot \mathrm{t}_{\mathrm{i}} \cdot \ln \left(\mathrm{t}_{\mathrm{i}}\right)+\mathrm{k}_{3} \cdot\left(\mathrm{t}-\mathrm{t}_{\mathrm{i}}\right)-\mathrm{k}_{4} \cdot\left(\mathrm{t}-\mathrm{t}_{\mathrm{i}}\right)\right]\right)} \\
\mathrm{C}_{1}(\mathrm{t})=\mathrm{C}_{\mathrm{li}}+\alpha \cdot\left(\mathrm{C}_{\mathrm{se}}-\mathrm{C}_{\mathrm{si}}\right) \cdot\left(\mathrm{e}^{\left(\mathrm{k}_{2} \cdot\left[-\left[\mathrm{k}_{3} \cdot \mathrm{t} \cdot \ln (\mathrm{t})+\mathrm{k}_{3} \cdot \mathrm{t}_{\mathrm{i}} \cdot \ln \left(\mathrm{t}_{\mathrm{i}}\right)+\mathrm{k}_{3} \cdot\left(\mathrm{t}-\mathrm{t}_{\mathrm{i}}\right)-\mathrm{k}_{4} \cdot\left(\mathrm{t}-\mathrm{t}_{\mathrm{i}}\right)\right]\right)\right.}-1\right)
\end{gathered}
$$

where $k_{2}, k_{3}, k_{4}$ are also parameters of the model $(1 / s)$.

Pseudo-second order empirical model - model 3

Empirical models for adsorption kinetics have been frequently used in the literature [23]. The most commonly used modeling approach deals with pseudo-second order models or Ho and McKay models [24] and the Elovich model [25]. The pseudo-first order model, also called Lagergren's equation [22], is eventually regarded as an empirical model in the literature [26,23], but it is important to emphasize that it can be obtained from a material balance similar to the pseudo-first order model with constant area, making it a semi-empirical model, since the parameters of the model were adjusted.

The pseudo-second order model is represented by the following system of differential equations:

$$
\begin{gathered}
\frac{\mathrm{dC}_{\mathrm{s}}}{\mathrm{dt}}=\mathrm{k}_{5} \cdot\left(\mathrm{C}_{\mathrm{s}}-\mathrm{C}_{\mathrm{se}}\right)^{2} \\
\frac{\mathrm{dC}_{1}}{\mathrm{dt}}=-\alpha \cdot \frac{\mathrm{dC}_{\mathrm{s}}}{\mathrm{dt}}=-\alpha \cdot \mathrm{k}_{5} \cdot\left(\mathrm{C}_{\mathrm{s}}-\mathrm{C}_{\mathrm{se}}\right)^{2}
\end{gathered}
$$

where $k_{5}$ the global coefficient, and the analytical solution is represented by Equations 13 and 14:

$$
\begin{gathered}
\mathrm{C}_{\mathrm{s}}(\mathrm{t})=\frac{\mathrm{C}_{\mathrm{si}}-\mathrm{k}_{5} \cdot \mathrm{C}_{\mathrm{se}} \cdot\left(\mathrm{C}_{\mathrm{si}}-\mathrm{C}_{\mathrm{se}}\right) \cdot\left(\mathrm{t}-\mathrm{t}_{\mathrm{i}}\right)}{1-\mathrm{k}_{5} \cdot\left(\mathrm{C}_{\mathrm{si}}-\mathrm{C}_{\mathrm{se}}\right) \cdot\left(\mathrm{t}-\mathrm{t}_{\mathrm{i}}\right)} \\
\mathrm{C}_{1}(\mathrm{t})=\mathrm{C}_{\mathrm{li}}-\alpha \cdot\left[\frac{\mathrm{C}_{\mathrm{si}}-\mathrm{k}_{5} \cdot \mathrm{C}_{\mathrm{se}} \cdot\left(\mathrm{C}_{\mathrm{si}}-\mathrm{C}_{\mathrm{se}}\right) \cdot\left(\mathrm{t}-\mathrm{t}_{\mathrm{i}}\right)}{1-\mathrm{k}_{5} \cdot\left(\mathrm{C}_{\mathrm{si}}-\mathrm{C}_{\mathrm{se}}\right) \cdot\left(\mathrm{t}-\mathrm{t}_{\mathrm{i}}\right)}-\mathrm{C}_{\mathrm{si}}\right]
\end{gathered}
$$




\section{Modeling the Equilibrium of the Process}

All proposed kinetic models depend on the concentration of mercury in the solid phase in an equilibrium condition $\left(\mathrm{C}_{\mathrm{se}}\right)$. In order to avoid the use of experimental data in the simulation of kinetic curves, an empirical expression was developed in order to establish a correlation between the property in question and the operating conditions. Towards this, Equation 15 has been derived from adsorption isotherms models that report a logarithmic dependence between the solid and liquid phase concentration of the adsorbent, such as Henderson-Henderson-Thompson, Chen-Clayton, Henderson [27] and Temkin [28], as follows:

$$
\mathrm{C}_{\mathrm{se}}=\left[\mathrm{b}_{1} \cdot \ln \left(\mathrm{C}_{\mathrm{li}}\right)\right]^{\mathrm{b}_{2}}+\mathrm{b}_{3} \cdot \ln \left(\mathrm{C}_{\mathrm{si}}+\mathrm{b}_{4}\right)
$$

where $b_{i}$ are the coefficients of the empirical correlation for calculation of concentration in the solid at equilibrium. The parameters of Equation 15 were determined by the Simplex optimization method, using as objective function the sum of the squared differences between the calculated and experimental values of $\mathrm{Hg}$ concentration in the solid phase at equilibrium.

The equilibrium concentrations of mercury in the solid and liquid phases were obtained at room temperature and at pH close to 7.0. However, the effects of the adsorbent type (macrophyte) and the initial concentration of mercury in the liquid and solid phase on the equilibrium ratios were also investigated. The fraction of the solid surface covered by mercury as a function of the concentration in the liquid phase was represented by four different isotherms, which can be observed in Table 1 [28-31], which are defined in Eqs. 16 to 19 , respectively, where $c_{i}$ are the empirical equilibrium constants:

Table 01. Types of isotherms used for process equilibrium analysis.

\begin{tabular}{ccc}
\hline Isotherm & Equilibrium Equation & Equation \\
Langmuir & $\frac{\mathrm{C}_{\mathrm{se}}}{\mathrm{C}_{\mathrm{semax}}}=\frac{\mathrm{c}_{1} \cdot \mathrm{C}_{\mathrm{le}}}{1+\mathrm{c}_{1} \cdot \mathrm{C}_{\mathrm{le}}}$ \\
Langmuir- & $\frac{\mathrm{C}_{\mathrm{se}}}{\mathrm{C}_{\mathrm{semax}}}=\frac{\mathrm{c}_{2} \cdot\left(\mathrm{C}_{\mathrm{le}}\right)^{\mathrm{c}_{3}}}{1+\mathrm{c}_{2} \cdot\left(\mathrm{C}_{\mathrm{le}}\right)^{\mathrm{c}_{3}}}$ \\
Hendlich & $\frac{\mathrm{C}_{\mathrm{se}}}{\mathrm{C}_{\mathrm{semax}}}=\left[\mathrm{c}_{4} \cdot \ln \left(\mathrm{C}_{\mathrm{le}}\right)\right]^{\frac{1}{\mathrm{c}_{5}}}$ \\
Redlich-Peterson & $\frac{\mathrm{C}_{\mathrm{se}}}{\mathrm{C}_{\mathrm{semax}}}=\frac{\mathrm{c}_{6} \cdot \mathrm{C}_{\mathrm{le}}}{1+\mathrm{c}_{6} \cdot\left(\mathrm{C}_{\mathrm{le}}\right)^{\mathrm{c}_{7}}}$
\end{tabular}

The maximum concentrations of mercury in the solid phase, at equilibrium, $\mathrm{C}_{\text {semax }}$, for each macrophyte were observed when the kinetic tests were carried out at the maximum initial concentrations of the metal in the liquid phase. However, after the second addition of the pollutant, a variation of $\mathrm{C}_{\text {semax }}$ was observed, with maximum value again evidenced at the maximum value of $\mathrm{C}_{\mathrm{li}}$.

The surface area of $1 \mathrm{~g}$ of biosorbent can be estimated from the maximum concentration of $\mathrm{Hg}$ at equilibrium, in the solid phase and after the second addition of mercury. Equation 20 summarizes the calculation procedure, which is reported in detail by Barrow [29]:

$$
\mathrm{A}=\left[\left(\frac{\mathrm{C}_{\mathrm{semax}}^{\mathrm{k}=2}}{10^{6} \cdot \rho_{\mathrm{Hg}}}\right) \cdot\left(\frac{6.03 \cdot 10^{23}}{24.8}\right)\right] \cdot\left[\left(\frac{\mathrm{MW}_{\mathrm{Hg}}}{10^{3} \cdot \rho_{\mathrm{Hg}}}\right) \cdot\left(\frac{1}{6.03 \cdot 10^{23}}\right)\right]^{\frac{2}{3}}
$$

where $\mathrm{C}_{\text {semax }}$ for $\mathrm{k}=2$ is the maximum equilibrium concentration of $\mathrm{HgCl}_{2}$ in the solid phase in ppm after the second injection of mercury, $\mathrm{PM}_{\mathrm{Hg}}$ is the molecular mass of $\mathrm{HgCl}_{2}(271,52 \mathrm{~g} / \mathrm{mol})$ and $\rho_{\mathrm{Hg}}$ is the density of $\mathrm{HgCl}_{2}\left(5440 \mathrm{g.l}^{-1}\right)$ [32].

\section{Adjusting Model Parameters}

The parameters of the models must be chosen to minimize the distance between the observed value and the value predicted by the model [33]. Thus, all parameters were determined in order to minimize the objective function represented by Equation 21, as follows: 


$$
\mathrm{f}=\left[\sum_{\mathrm{i}=1}^{\mathrm{N}}\left(\frac{\mathrm{C}_{\mathrm{s}}^{\text {calc, }}-\mathrm{C}_{\mathrm{s}}^{\text {exp, }}}{\mathrm{C}_{\mathrm{s}}^{\text {exp,i }}}\right)^{2}\right] \cdot\left[\sum_{\mathrm{i}=1}^{\mathrm{N}}\left(\frac{\mathrm{C}_{1}^{\text {calc,i }}-\mathrm{C}_{1}^{\text {exp }, \mathrm{i}}}{\mathrm{C}_{1}^{\text {exp }, \mathrm{i}}}\right)^{2}\right]
$$

where $\mathrm{N}$ is the total number of experiments involving simultaneous measurements of $\mathrm{C}_{\mathrm{s}}$ and $\mathrm{C}_{\mathrm{l}}$, calculated by the models $\left(\mathrm{C}_{s}{ }^{\text {calc, },}, \mathrm{C}_{l}{ }^{\text {calc, }}\right)$ and the data obtained experimentally $\left(\mathrm{C}_{s}{ }^{\text {exp,i },}, \mathrm{C}_{l}{ }^{\text {exp, },}\right)$. The Simplex Method was used in all optimization calculations of the above functions.

In the parameter estimation procedure of $k_{1}$, the values of $C_{s}(t)$ were calculated by Equation 3 , while those of $\mathrm{C}_{\mathrm{l}}(\mathrm{t})$ were estimated by an alternative expression given by Equation 22:

$$
\mathrm{C}_{1}(\mathrm{t})=\mathrm{C}_{\mathrm{le}}-\left(\mathrm{C}_{\mathrm{le}}-\mathrm{C}_{\mathrm{li}}\right) \cdot \mathrm{e}^{\mathrm{k}_{\mathrm{l}} \cdot\left(\mathrm{t}-\mathrm{t}_{\mathrm{i}}\right)}
$$

which was obtained by solving the Equation 23:

$$
\frac{\mathrm{dC}_{1}}{\mathrm{dt}}=\mathrm{k}_{1} \cdot\left(\mathrm{C}_{1}-\mathrm{C}_{\mathrm{le}}\right)
$$

The values of $C_{s}(t)$ involved in the adjustment of parameters $k_{2}, k_{3}, k_{4}$ were calculated by Equation 9 , while those of $\mathrm{C}_{\mathrm{s}}(\mathrm{t})$ were estimated by an alternative expression to Equation 10, resulting in Equation 24:

$$
\mathrm{C}_{1}(\mathrm{t})=\mathrm{C}_{\mathrm{le}}+\left(\mathrm{C}_{\mathrm{le}}-\mathrm{C}_{\mathrm{li}}\right) \cdot \mathrm{e}^{\mathrm{k}_{2} \cdot\left[-\mathrm{k}_{3} \cdot \mathrm{t} \cdot \ln (\mathrm{t})+\mathrm{k}_{3} \cdot \mathrm{t}_{\mathrm{i}} \cdot \ln \left(\mathrm{t}_{\mathrm{i}}\right)+\mathrm{k}_{3} \cdot\left(\mathrm{t}-\mathrm{t}_{\mathrm{i}}\right)-\mathrm{k}_{4} \cdot\left(\mathrm{t}-\mathrm{t}_{\mathrm{i}}\right)\right]}
$$

obtained by solution of Equation 25:

$$
\frac{\mathrm{dC}_{1}}{\mathrm{dt}}=\mathrm{k}_{2} \cdot\left(\mathrm{k}_{3} \cdot \ln (\mathrm{t})+\mathrm{k}_{4}\right) \cdot\left(\mathrm{C}_{1}-\mathrm{C}_{\mathrm{le}}\right)
$$

In the adjustment of parameter $k_{5}$, the calculated values of $\mathrm{C}_{\mathrm{s}}(\mathrm{t})$ were obtained by Equation 13 , while Equation 14 was replaced by Equation 26, as follows:

$$
\mathrm{C}_{1}(\mathrm{t})=\frac{\mathrm{C}_{\mathrm{li}}-\left(\frac{-\mathrm{k}_{5}}{\alpha}\right) \cdot \mathrm{C}_{\mathrm{le}} \cdot\left(\mathrm{C}_{\mathrm{li}}-\mathrm{C}_{\mathrm{le}}\right) \cdot\left(\mathrm{t}-\mathrm{t}_{\mathrm{i}}\right)}{1-\left(\frac{-\mathrm{k}_{5}}{\alpha}\right) \cdot\left(\mathrm{C}_{\mathrm{li}}-\mathrm{C}_{\mathrm{le}}\right) \cdot\left(\mathrm{t}-\mathrm{t}_{\mathrm{i}}\right)}
$$

which represents the solution of Equation 27:

$$
\frac{\mathrm{dC}_{1}}{\mathrm{dt}}=-\frac{\mathrm{k}_{5}}{\alpha} \cdot\left(\mathrm{C}_{1}-\mathrm{C}_{\mathrm{le}}\right)^{2}
$$

The Equations 23, 25 and 27 were respectively obtained by replacing $\mathrm{C}_{\mathrm{s}}(\mathrm{t})$ given by Equation 28 in Equations 2, 8 and 12, as follows:

$$
\mathrm{C}_{\mathrm{s}}(\mathrm{t})=\frac{\mathrm{C}_{1}(\mathrm{t})}{\alpha}
$$

The variable $\alpha$ was determined in order to reproduce data of variation of mercury concentration in the liquid phase in each different experimental condition investigated, involving Equation 4 to calculate $\mathrm{C}_{\mid}(\mathrm{t})$. Different values of $\alpha$ were obtained as a function of the initial concentrations in the liquid and solid phases by the Levenberg-Marquardt Method. The parameters of Equation 29, presented below, were adjusted with the Simplex optimization method to reproduce the $\alpha$ data obtained for the different macrophytes as a function of the initial concentrations of mercury in the solid and liquid phases:

$$
\alpha=\left[\mathrm{a}_{1} \cdot \ln \left(\mathrm{C}_{\mathrm{li}}\right)\right]^{\mathrm{a}_{2}}+\mathrm{a}_{3} \cdot \ln \left(\mathrm{C}_{\mathrm{si}}+\mathrm{a}_{4}\right)
$$

where $a_{i}$ are the coefficients of empirical correlation. 


\section{RESULTS}

The step of analysis of the mechanism involved in the process, as well as the determination of adsorption rate, play an important role in the choice of the process to be used in the treatment of contaminated effluents. In addition, the mathematical model is of fundamental importance to provide realistic information regarding residence time, concentration profiles, among other data. Therefore, in order to study the pollutant removal characteristics of aqueous solutions promoted by the different types of algae studied, the concentrations of $\mathrm{Hg}$ in solution and algae were evaluated. For this, the profiles of $\mathrm{Hg}$ concentration as a function of adsorption time were constructed for the macrophytes E. crassipes, E. azurea and S. ariculata, which can be observed in Figures 1 to 3 . The experimental data are compared with the results obtained from the pseudo-first order model with constant area (model 1), pseudo-first order model with variable area (model 2) and pseudosecond order model (model 3), whose parameters are reported in Table 2.

Table 2. Parameters of pseudo-first order models with constant area (model 1), pseudo-first order with variable area (model 2) and pseudo-second order (model 3).

\begin{tabular}{cccccc}
\hline Model & $\mathbf{k}_{\mathbf{1}}$ & $\mathbf{k}_{\mathbf{2}}$ & $\mathbf{k}_{\mathbf{3}}$ & $\mathbf{k}_{\mathbf{4}}$ & $\mathbf{k}_{\mathbf{5}}$ \\
\hline 1 & 0.07067 & - & - & - & - \\
2 & - & 0.08636 & 0.1031 & 0.6277 & - \\
3 & - & - & - & - & 0.002917
\end{tabular}

In addition to the constants reported in Table 2, all proposed models depended on the correct estimation of $\mathrm{C}_{\mathrm{se}}$ by application of Equation 15, whose parameters are reported in Table 3.

Table 3. Empirical correlation coefficients (Equation 15) for the calculation of $\mathrm{C}_{\text {se }}$ in the different investigated conditions.

\begin{tabular}{ccccc}
\hline Macrophyte & $\mathbf{b}_{\mathbf{1}}$ & $\mathbf{b}_{\mathbf{2}}$ & $\mathbf{b}_{\mathbf{3}}$ & $\mathbf{b}_{\mathbf{4}}$ \\
\hline E. crassipes & 0.673 & 3.381 & 74.370 & 0.490 \\
E. azurea & 0.505 & 4.457 & 42.100 & 0.0411 \\
S. ariculata & 1.205 & 2.892 & 81.433 & 0.505 \\
\hline
\end{tabular}

The calculation of the concentration of mercury in the liquid phase as a function of the concentration in the solid phase in equilibrium with Equations 4, 10 and 14 involved values of $\alpha$ determined by Equation 29, with parameters presented in Table 4.

Table 4. Empirical correlation coefficients (Equation 29) for calculating the ratio in the different investigated conditions.

\begin{tabular}{ccccc} 
Macrophyte & $\mathbf{a}_{\mathbf{1}}$ & $\mathbf{a}_{\mathbf{2}}$ & $\mathbf{a}_{\mathbf{3}}$ & $\mathbf{a}_{\mathbf{4}}$ \\
E. crassipes & 0.224 & 3.477 & -0.496 & 0.0116 \\
E. azurea & 0.277 & 2.820 & -0.889 & 2.327 \\
S. ariculata & 0.175 & 3.768 & -0.106 & 0.164 \\
\hline
\end{tabular}

Figures 1 to 3 show the solid and liquid phase concentration profiles and the strong dependence of the investigated models with the correct estimation of the $\mathrm{Hg}$ concentration in the solid phase at equilibrium. The largest differences between the calculated and experimental values of concentration in the solid for $E$. azurea, observed in Figure 2 (a) for $\mathrm{C}_{\mathrm{li}}=500 \mathrm{ppb}$ and $\mathrm{C}_{\mathrm{l}}=1000 \mathrm{ppb}$, are clearly attributed to a failure to estimate this variable through the proposed empirical equation.
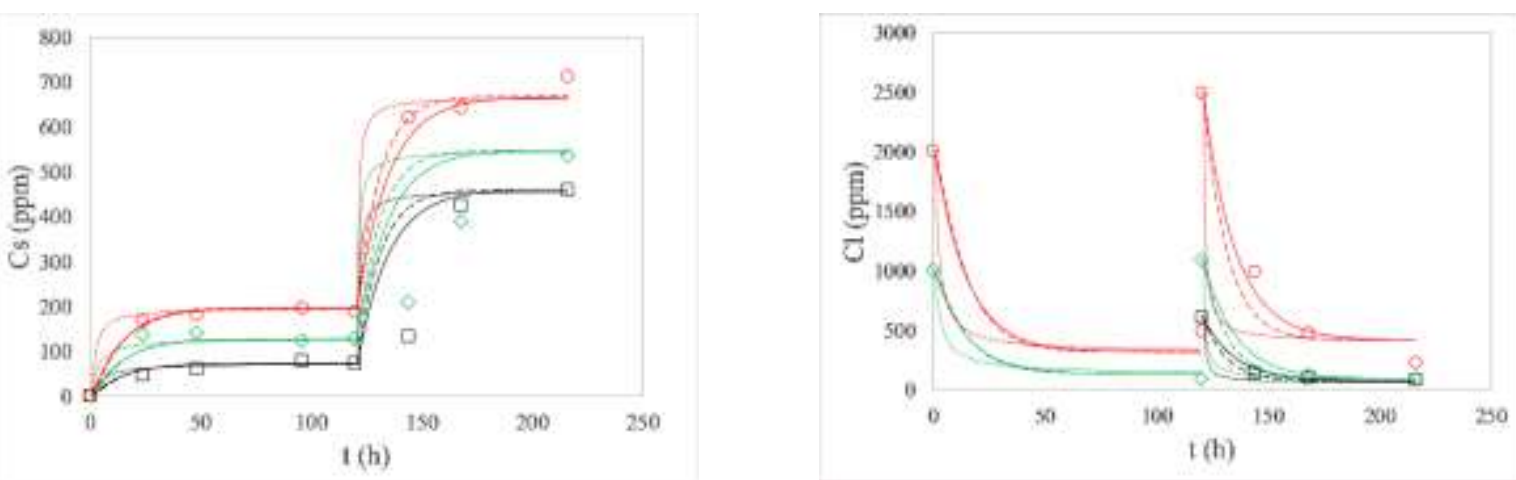
(a)

(b)

Figure 1. Kinetic of the sorption of $\mathrm{Hg}$ for E. crassipes: (a) in the solid and (b) in the liquid. Color black: $\mathrm{C}_{\mathrm{li}}=500 \mathrm{ppb}$; Color green: $\mathrm{C}_{\mathrm{li}}=1000 \mathrm{ppb}$; Color red: $\mathrm{C}_{\mathrm{li}}=2000$ ppb. Symbols: experimental results; continuous line: model 1; Dashed line: model 2; dotted line: model 3.

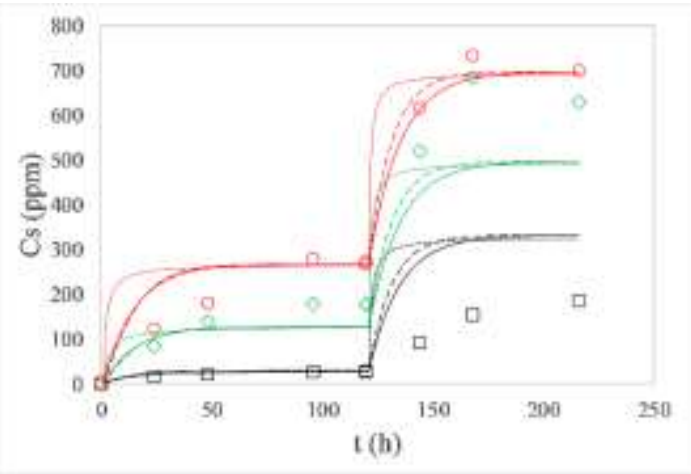

(a)

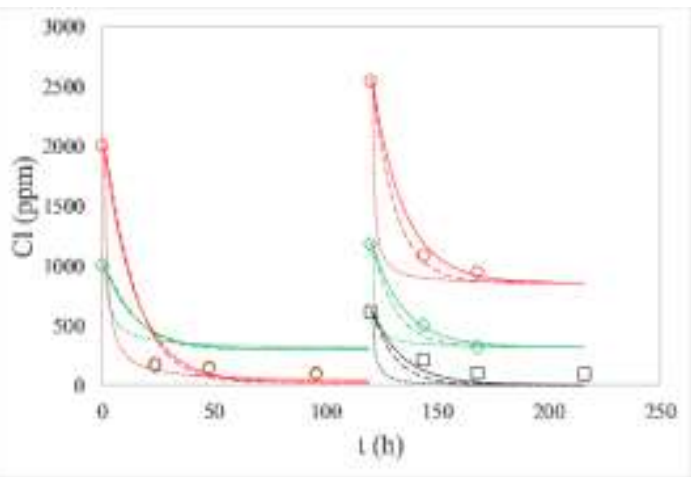

(b)

Figure 2. Kinetic of the sorption of $\mathrm{Hg}$ for E. azurea: (a) in the solid and (b) in the liquid. Color black: $\mathrm{Cli}_{\mathrm{i}}=500 \mathrm{ppb}$; Color green: $\mathrm{C}_{\mathrm{li}}=1000 \mathrm{ppb}$; Color red: $\mathrm{C}_{\mathrm{li}}=2000 \mathrm{ppb}$. Symbols: experimental results; continuous line: model 1; Dashed line: model 2; dotted line: model 3.

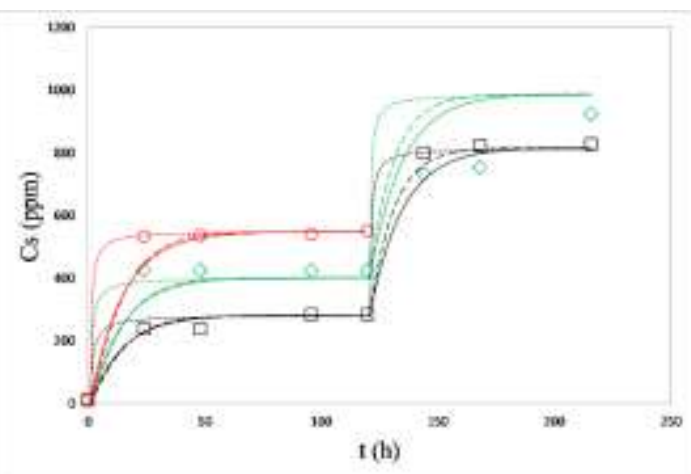

(a)

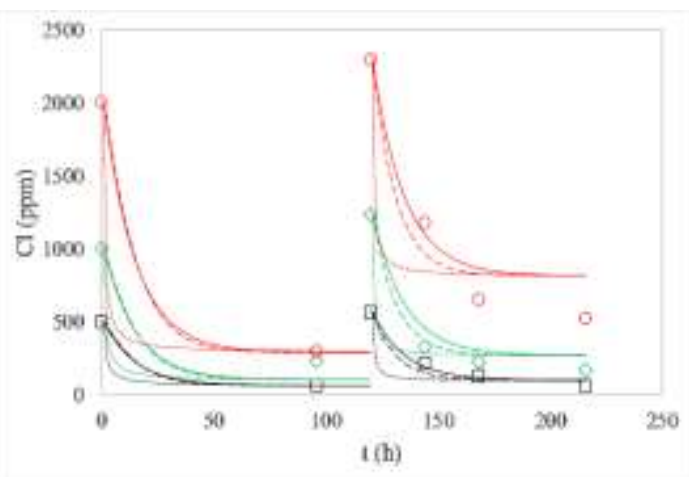

(b)

Figure 3. Kinetic of the sorption of $\mathrm{Hg}$ for E. ariculata: (a) in the solid and (b) in the liquid. Color black: $\mathrm{Cli}_{\mathrm{i}}=500 \mathrm{ppb}$; Color green: $\mathrm{C}_{l i}=1000 \mathrm{ppb}$; Color red: $\mathrm{C}_{l i}=2000 \mathrm{ppb}$. Symbols: experimental results; continuous line: model 1; Dashed line: model 2; dotted line: model 3.

However, the correct representation of the kinetic concentration profiles by the suggested models, as well as the negligible deviations between experimental and calculated values of $\mathrm{C}_{\text {se }}$, can be observed in Figure 4, indicating the validity of Equation 15 for calculating the data of equilibrium in the solid phase in the different conditions adopted in the experiments.

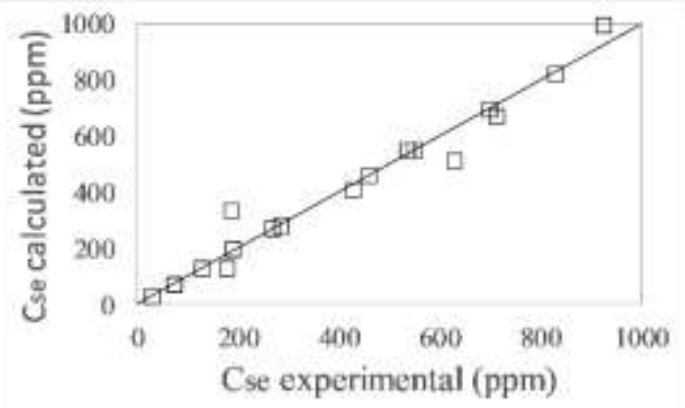

Figure 4. Comparison between calculated and experimental values of $\mathrm{Hg}$ concentration in the solid phase at equilibrium for the macrophytes investigated.

In order to evaluate which model best describes the experimental data, the determination coefficients were calculated, according to Table 5, which, closer to the unit, the better the quality of the data fitting. 
Table 5. Determination coefficients obtained for the different analyzed models, for the solid and liquid phases.

\begin{tabular}{cccc}
\hline & \multicolumn{4}{c}{ Determination coefficient $\left(\mathbf{R}^{\mathbf{2}}\right)$} \\
\hline Model & $\mathbf{1}$ & $\mathbf{2}$ & $\mathbf{3}$ \\
Solid phase & 0.97 & 0.97 & 0.96 \\
Liquid phase & 0.93 & 0.96 & 0.93 \\
\hline
\end{tabular}

Thus, model 1, which involves only two adjustable parameters $\left(k_{1} e \alpha\right)$ (compared to four parameters of model 2 and two parameters of model 3), represents the concentrations of $\mathrm{Hg}$ in the solid phase with smaller deviations from the data experimental results, since it presents the closest to 1 determination coefficient. However, the lowest deviations from the experimental data were obtained for the model 2. The surface area growth as a function of time, adopted empirically, should in fact result in a higher rate of adsorption of $\mathrm{Hg}$ when considered the same experimental conditions and a same time of test, as is systematically evidenced in the kinetic curves.

The behavior of the pseudo-second order model is also readily understood. As the concentration variation in the solid phase, as well as in the liquid phase, is proportional to the square of the concentration gradients, naturally the slopes of the kinetic curves are more abrupt in the initial periods of adsorption.

In agreement with the reported results of Crini and Badot [34] it is evidenced that the pseudo first order model, which is represented by an algebraic expression similar to Equation 3, considers that the adsorption is attributed to a gradient of concentration between the surface of the adsorbate and the solution [34]. In addition, it is assumed that generally this model adequately represents the adsorption results only in the initial stages, when theoretically the external convection controls the process [23]. This last hypothesis is a possible reason that makes the pseudo-first order constant area model the most able to represent the experimental results obtained, since it is accurate in the period of constant adsorption velocity that the other models fail to reproduce the experimental behavior.

The pseudo-second order model theoretically considers the external and internal mass transfer [24], in addition to admitting chemosorption as the dominant stage [34], which usually causes it to be preferred to model 01 by many authors [23]. However, since a single value has been obtained for the effective mass transport coefficient for the different types of macrophytes, it is probable that external convection is the dominant stage in the mercury adsorption process by the studied macrophytes.

The Elovich model [25] assumes that the adsorption rate decreases due to saturation of the active surface sites. Since this phenomenon is represented in the pseudo-first-order variable-area model, one can assume that they are analogous. However, the residual difference between the concentration values calculated by model 1 and 2 indicates that the reduction of the surface area has no effect on adsorption kinetics.

In Figures 1 to 3 , it is also important to note that the consecutive feedings of mercury in the time in the bed of adsorption, at time zero and $120 \mathrm{~h}$, are treated discontinuously by the proposed models. The increase in the concentrations in the solid phase after the second feed are attributed to the increase in the equilibrium concentration. Similarly, an increase in the equilibrium concentrations due to the increase in the initial concentration of $\mathrm{Hg}$ in the liquid phase, responsible for higher amounts of $\mathrm{Hg}$ in the solid phase, will be treated.

The effect of the initial concentrations on both phases is clearly shown in Figure 5. As already reported by other authors [26,35], the increase of the initial concentration of the solution of adsorbate causes an increase of the equilibrium concentration.

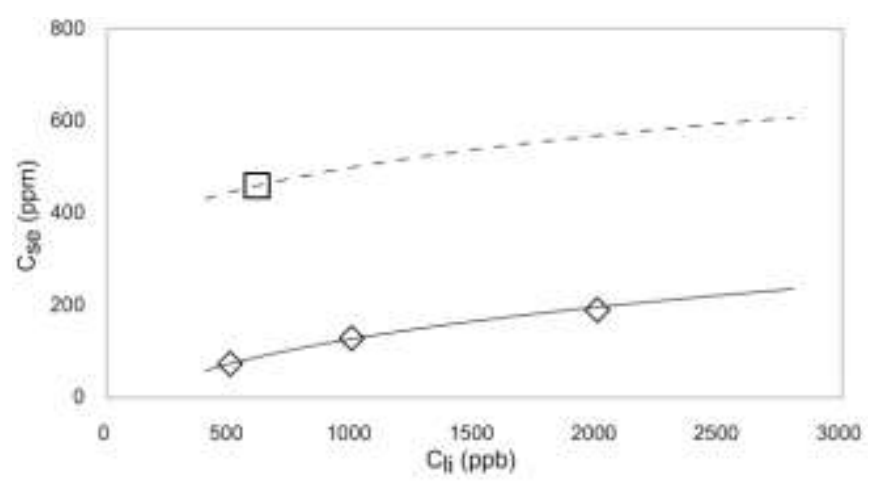

Figure 5. Effect of initial adsorbate concentration on the liquid $\left(\mathrm{C}_{\mathrm{li}}\right)$ and solid phase $\left(\mathrm{C}_{\mathrm{si}}\right)$ on the calculated concentration (lines) and equilibrium experimental (symbols) for $E$. crassipes. Continuous line and lozenges: $\mathrm{C}_{\mathrm{si}}=0.0 \mathrm{ppm}$ ( $1^{\text {st }}$ injection of $\mathrm{Hg}$ ); dashed line and squares: $\mathrm{C}_{\mathrm{si}}=73 \mathrm{ppm}\left(2^{\text {nd }}\right.$ injection of $\mathrm{Hg}$ ). 
The Figure 5 also demonstrates the growth of $\mathrm{C}_{\text {se }}$ when the macrophytes already subjected to contact with mercury, that is, with initial concentrations of $\mathrm{Hg}$ other than zero, were again immersed in adsorbate solutions larger than the equilibrium ones. This fact is attributed to the increase of the $\mathrm{Hg}$ concentration gradient between the phases, which causes a greater mobility of adsorbate in the solution, promoting the occupation of active sites not found by the remaining mercury in the liquid phase in the first state of equilibrium observed in the temporal profile concentration in the solid phase.

Furthermore, the Figure 5 shows that increasing the initial concentration of the pollutant in the solution increases the $\mathrm{Hg}$ concentration at equilibrium. Since a greater amount of mercury is being adsorbed in the solid phase due to the increase of this factor, in the same proportion increases the quantity of pollutant to leave the liquid phase. In this sense, the model assumes that a larger mass of adsorbent should be present in the control volume, as reported in Figure 6. Also, it must be emphasized that the macrophyte mass in the solutions cannot have increased as a function of the increase of the initial concentration of mercury.

Therefore, Figure 4 validates Equation 15 for $\mathrm{C}_{\text {se }}$ calculation, Figure 6 gives consistency to the results of the ratio $\alpha$ obtained by Equation 29. Despicable deviations are observed between the calculated and adjusted values of $\alpha$ to keep the mass of mercury constant in the control volume.

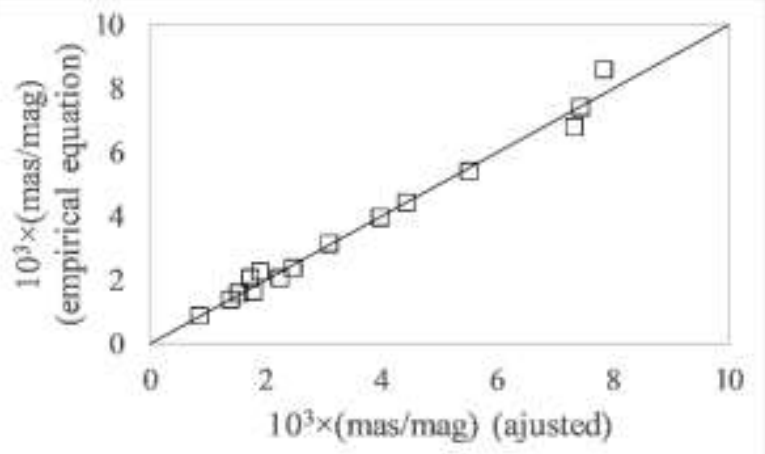

Figure 6. Relationship between the values of $\alpha$ adjusted and obtained by the empirical equation.

In fact, results obtained after consecutive mercury feeds at similar initial concentrations, reported in Figure 7, indicate a mortality of macrophytes due to the presence of mercury, as reported by Muramoto and Oki [17] and Mendes et al. [36]. This evidence can be observed by the reduction of the ratio due to the increase of the initial concentration of the pollutant in the liquid phase, for a constant ratio between the mass of adsorbent and water in the solution.

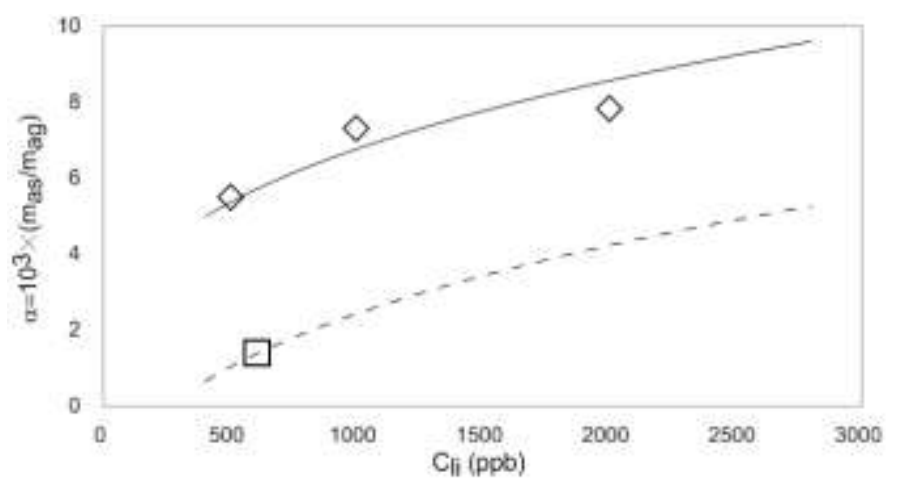

Figure 7. Effect of initial adsorbate concentration on the liquid $\left(\mathrm{C}_{\mathrm{li}}\right)$ and solid $\left(\mathrm{C}_{\mathrm{si}}\right)$ phase on the ratio $\alpha$ calculated with Equation 10 and adjusted to reproduce profiles of mercury concentration in the liquid phase for $E$. crassipes. Continuous line and lozenges: $\mathrm{Csi}=0.0 \mathrm{ppm}\left(1^{\text {st }}\right.$ injection of $\mathrm{Hg}$ ); dashed line and squares: $\mathrm{C}_{\mathrm{si}}=73 \mathrm{ppm}\left(2^{\text {nd }}\right.$ injection of $\left.\mathrm{Hg}\right)$.

Already the Figure 8 show the equilibrium isotherms adjusted for the three types of macrophytes. 


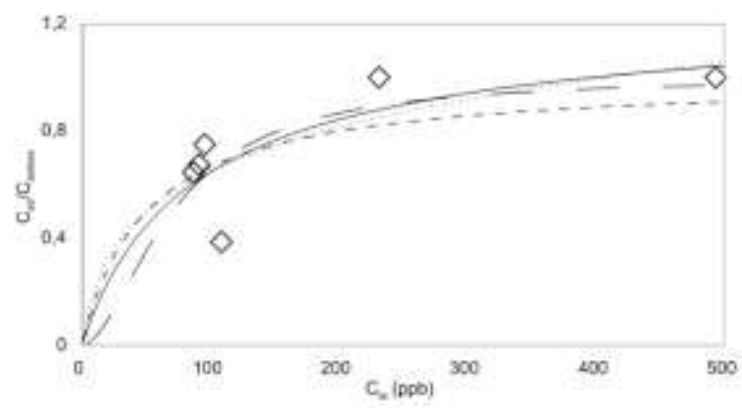

(a)

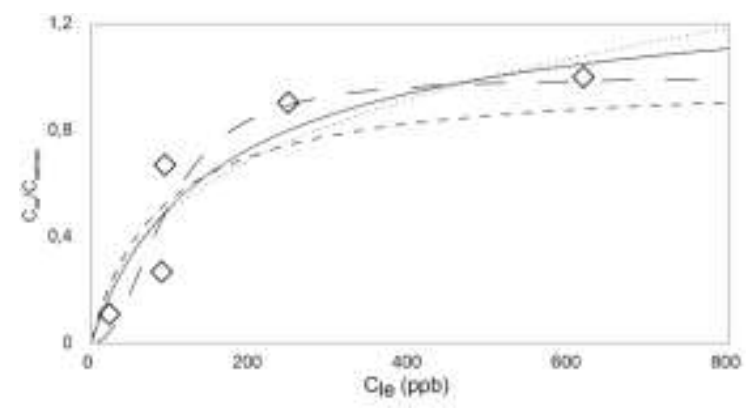

(b)

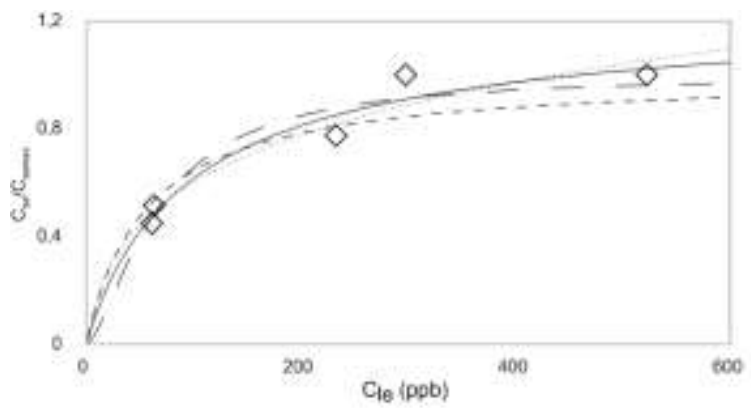

(c)

Figure 8. Equilibrium isotherms at room temperature for: (a) E. crassipes, (b) E. azurea, (c) S. ariculata. Line with short strokes: Langmuir; line with long strokes: Langmuir-Freundlich; dotted line: Henderson; solid line: Redlich-Peterson.

In order to evaluate the quality of fit, the mean determination coefficients for Langmuir, LangmuirFreundlich, Henderson and Redlich-Peterson isotherms were calculated, whose values are $0.71,0.78,0.77$ and 0,79 , respectively. Thus, the calculated values for the determination coefficients indicate that the RedlichPeterson isotherm best describes the equilibrium ratio between $\mathrm{Hg}$ concentrations in the solid and liquid phase. The parameter $c_{3}$ of the Langmuir-Freundlich equation characterizes the degree of surface heterogeneity [37]. The lower the value of this parameter, the better the adsorptive features of the material [26]. In fact, the results of $c_{3}$ show, as already observed in the kinetic profiles of mercury concentration, that $S$. ariculata has the highest adsorption capacity of this pollutant since for this macrophyte $c_{3}=1.55$, while for the other the value is greater than 1.79. Despite this fact, values of $c_{3}$ higher than unity indicate adsorbents with poorer sorption characteristics.

The specific surface areas of the biosorbents indicated in Table 6 corroborate the adsorptive capacities of the same. The larger surface area of $E$. crassipes than that of $E$. azurea explains the lower value of $\mathrm{C}_{3}$ of the first plant when compared to that of the second. In addition, as indicated by the analysis of $c_{3}$ values, the macrophyte with the highest adsorption potential presents a surface area well below those found in the best adsorbents. Despite this, considering the volume and cost of material required in a heavy metal treatment plant, it is considered that the macrophytes investigated have considerable potential for removal of mercury from wastewater.

Table 6. Surface area per g of biosorbent according to Equation 20.

\begin{tabular}{ccc}
\hline Macrophytes & $\mathbf{C}_{\text {semax }}(\mathbf{k}=\mathbf{2})(\mathbf{p p m})$ & $\mathbf{A}\left(\mathbf{m}^{2} \cdot \mathbf{g}^{-1}\right)$ \\
\hline E. crassipes & 713.5 & $6.06 \times 10^{-4}$ \\
E. azurea & 698.5 & $5.93 \times 10^{-4}$ \\
S. ariculata & 1858.1 & $15.77 \times 10^{-4}$ \\
\hline
\end{tabular}

The data set reported by Rodrigues [16] refers to the experimental data obtained for the concentration of mercury in the different types of macrophytes at predetermined time intervals.

Similarly, the potential of mercury removal using living algae has been investigated by several authors [14,39-41]. Skinner et al.[39] evaluated use of four different types of living algae, including E. crassipes, in the mercury removal in aqueous solutions with different initial concentrations. The experiments were carried out at constant temperature $\left(22^{\circ} \mathrm{C}\right)$ and $\mathrm{pH}$ near neutrality, resulting in a positive correlation, where the higher the level of exposure to mercury, the greater the removal. Kamal et al.[41] also worked with living plants, constant temperature $\left(17^{\circ} \mathrm{C}\right)$ and reported the dependence between the rate of removal of heavy metals and 
the initial concentration of the contaminant in the medium, similarly to the results of the study here reported. Furthermore, Ghabbour et al. [40] suggested that E.crassipes exhibits binding properties with the metals, stressing its features as a contaminant sorbent. In addition, complementary studies, varying experimental conditions such as $\mathrm{pH}$, medium temperature, type and concentration of algae, initial concentration of the solution among others, were suggested in order to better explore the potential of living algae.

\section{CONCLUSION}

The three different mathematical models proposed successfully described the influence of the investigated factors (macrophyte type, adsorption time, initial concentrations of mercury in the liquid and solid phases) on the dynamics of the process. It was verified, through the analysis of the determination coefficients, that the model 1 represented the concentrations of $\mathrm{Hg}$ (II) in the solid phase with smaller deviations in relation to the experimental data. In the liquid phase, the smallest deviations were observed by model 2. Even so, the observed differences between the kinetic profiles calculated with the different models were only residual.

In equilibrium conditions, the relationships between the mercury concentrations in the fluid phase and the adsorbent at ambient temperature conditions were correctly described by the adsorption isotherms of Langmuir, Langmuir-Freundlich, Henderson and Redlich-Peterson. The coefficient of determination closest to the unit was obtained by the Redlich-Peterson model, although the Langmuir and Freundlich isotherms are the most widely used. The $\mathrm{c}_{3}$ parameter of the Langmuir-Freundlich equation, which characterizes the degree of surface heterogeneity [37], reveals that $S$. ariculata has the highest adsorption capacity of mercury, since for this macrophyte $c_{3}=1.55$, while for the others the value is higher than 1.79 . The specific areas of adsorption calculated, the maximum concentration of mercury at equilibrium for the different macrophytes and the kinetic profiles of mercury concentration corroborate this evidence. The value of parameter $\mathrm{c}_{3}$ greater than unity and the reduced surface areas indicate that the biosorbents in question have poor sorption characteristics.

However, considering the large volume of adsorbent material required in a heavy metal treatment plant and the, as also observed by Kadirvelu et al.[15], low cost of the analyzed adsorbents it is concluded that the macrophytes investigated can be used as alternative for the removal of mercury from wastewater.

Acknowledgments: The authors thank CNPQ and CAPES (Brazilian Agencies) for the scholarships and financial support.

Conflicts of Interest: The authors declare no conflict of interest.

\section{REFERENCES}

1. He J, Chen P. A comprehensive review on biosorption of heavy metals by algal biomass: materials, performances, chemistry, and modeling simulation tools. Bioresource Technol. 2014; 160, 67-78.

2. Ramadan $\mathrm{H}$, Ghanem A, El-Rassy $\mathrm{H}$. Mercury removal from aqueous solutions using silica, polyacrylamide and hybrid silica-polyacrylamide aerogels. Chem Eng J. 2010; 159(1-3): 107-115.

3. Namasivayam C, Kadirvelu K. Uptake of mercury (II) from wastewater by activated carbon from an unwanted agricultural solid by-product: coirpith. Carbon. 1999; 37(1): 79-84.

4. Yardim MF, Budinova T, Ekinci E, Petrov N, Razvigorova M, Minkova V. Removal of mercury (II) from aqueous solution by activated carbon obtained from furfural. Chemosphere. 2003; 52(5): 835-841.

5. Tuzen M, Sari A, Mendil D, Soylak M. Biosorptive removal of mercury (II) from aqueous solution using lichen (Xanthoparmelia conspersa) biomass: kinetic and equilibrium studies. J Hazard Mater. 2009; 169(1-3): 263-270.

6. El-Shafey El. Removal of $\mathrm{Zn}$ (II) and $\mathrm{Hg}$ (II) from aqueous solution on a carbonaceous sorbent chemically prepared from rice husk. J Hazard Mater. 2010; 175(1-3): 319-327.

7. Deng L, Zhu X, Wang X, Su Y, Su H. Biosorption of copper (II) from aqueous solutions by green alga cladophora fascicularis. Biodegradation. 2007; 18(4): 393-402.

8. Amirnia S, Ray MB, Margaritis A. Heavy metals removal from aqueous solutions using saccharomyces cerevisiae in a novel continuous bioreactor-biosorption system. Chem Eng J. 2015; 264: 863-872.

9. Sari A, Tuzen M. Removal of mercury (II) from aqueous solution using moss (drepanocladus revolvens) biomass: equilibrium, thermodynamic and kinetic studies. J Hazard Mater. 2009; 171(1-3): 500-507.

10. Çolak F, Atar N, Yazicioglu D, Olgun A. Biosorption of lead from aqueous solutions by bacillus strains possessing heavy-metal resistance. Chem Eng J. 2011; 173(2): 422-428.

11. Kapoor A, Viraraghavan T. Fungal biosorption - an alternative treatment option for heavy metal bearing wastewaters: a review. Bioresource Technol. 1995; 53 (3): 195-206. 
12. Romera E, González F, Ballester A, Blázquez ML, Muñoz JA. Comparative study of biosorption of heavy metals using different types of algae. Bioresource Technol. 2007; 98: 3344-3353.

13. Kumar D, Pandey LK, Gaur JP. Metal Sorption by Algal Biomass: from Batch to Continuous System. Algal Res. 2016; 18: 95-109.

14. Casagrande GCR, Dos Reis C, Arruda R, De Andrade RLT, Battirola LD. Bioaccumulation and biosorption of mercury by Salvinia biloba raddi (salviniaceae). Water Air Soil Pollut. 2018; 229(5):166.

15. Kadirvelu K, Kanmani P, Senthilkumar P, Subburam V. Separation of mercury (II) from aqueous solution by adsorption onto an activated carbon prepared from Eichhornia crassipes. Adsorpt Sci Technol. 2004; 22(3):207222.

16. Rodrigues BA. Estudo da potencialidade de plantas aquáticas do rio paraná, região de Porto Rico - PR, de despoluir efluentes contaminados por mercúrio [dissertation]. Maringá (PR): State University of Maringá; 1991.

17. Muramoto S, Oki Y. Removal of some heavy metals from polluted water by water hyacinth (Eichhornia crassipes). Bull Environ Contam Toxicol. 1983; 30(2): 170-177.

18. Rodrigues BA, Lenzi E, Luchese EB. Estudo da potencialidade de plantas aquáticas do rio paraná, região de Porto Rico - PR, de despoluir efluentes contaminados por mercúrio. Proceedings of 4th Encontro Nacional de Estudos sobre o Meio Ambiente; 1993. Cuiabá, MT.

19. Gorsuch TT. Radiochemical investigations on the recovery for analysis of trace elements in organic and biological materials. Analyst. 1959; 84: 135-177.

20. Analytical Methods Committee. The determination of small amounts of mercury in organic matter. Analyst. 1965; 90: 515-530.

21. Omang SH. Determination of mercury in natural waters and effluents by flameless atomic absorption spectrophotometry. Anal Chim Acta. 1971; 53(2): 415-420.

22. Lagergren S. Zur theorie der sogenannten adsorption gelöster stoffe, kungliga svenska vetenskapsakademiens. Handl. 1898; 24: 1-39.

23. Piccin JS, Dotto GL, Vieira MLG, Pinto LAA. Cinética de adsorção do corante alimentício fd \& $c$ vermelho $n^{\circ} 40$ por quitosana. Proceedings of XXXIV Congresso Brasileiro de Sistemas Particulados; 2009. Campinas, SP.

24. Skodras G, Diamantopoulou IR, Pantoleontos G, Sakellaropoulos GP. Kinetic studies of elemental mercury adsorption in activated carbon fixed bed reactor. J Hazard Mater. 2008; 158(1): 1-13.

25. Wu FC, Tseng RL, Juang RS. Characteristics of Elovich equation used for the analysis of adsorption kinetics in dye chitosan systems. Chem Eng J. 2009; 150 (2-3): 366-373.

26. Vieira MGA, Neto AFA, Silva MGC. Estudo cinético e termodinâmico de adsorção de níquel em argila bentonita tipo bofe. Proceedings of XXXIV Congresso Brasileiro de Sistemas Particulados, 2009 Campinas, SP.

27. Zanoelo EF. Equilibrium moisture isotherms for mate leaves. Biosyst Eng. 2005; 92(4): 445-452.

28. Thomas JM, Thomas WJ. Principles and Practice of Heterogeneous Catalysis. Weiheim: VCH; 1997.

29. Barrow GM. Physical Chemistry. 5th ed. New York: McGraw-Hill International Editions; 1988.

30. Alleoni LRF, Camargo AO, Casagrande JC. Isotermas de Langmuir e Freundlich na descrição da adsorção de boro em solos altamente intemperizados. Sci Agric. 1998; 55 (3).

31. Klug M, Sanches MNM, Laranjeira MCM, Fávere VT, Rodrigues CA. Análise das isotermas de adsorção de Cu (II), $\mathrm{Cd}(\mathrm{II}), \mathrm{Ni}(\mathrm{II})$ e $\mathrm{Zn}$ (II) pela N-(3,4-dihidroxibenzil) quitosana empregando o método da regressão não linear. Quim Nova. 1998; 21 (4): 410-413.

32. Perry $\mathrm{RH}$, Chilton $\mathrm{CH}$. Manual de Engenharia Química. 5th ed. Rio de Janeiro: Guanabara Dois. 1980.

33. Johnson RA, Wichern DW. Applied Multivariate Statistical Analysis. 5th ed. Upper Saddle River: Prentice-Hall. 2002.

34. Crini G, Badot PM. Application of chitosan, a natural aminopolysaccharide, for dye removal from aqueous solutions by adsorption processes using batch studies: A review of recent literature. Prog Polym Sci. 2008; 33(4): 399-447.

35. Welty JR, Wicks CE, Wilson RE. Fundamentals of Momentum, Heat and Mass Transfer. 3rd ed. New York: John Wiley and Sons. 1984.

36. Mendes PLA, Meyer ST, Noronha IAS, Gomes SMA, Santos MH. Alterações morfológicas em Eichhornia crassipes (aguapé) (Mart.) Solms-Laubach (Pontederiaceae), exposta a elevadas concentrações de mercúrio. Pesticidas Revista de Ecotoxicologia e Meio Ambiente. 2009; 19, $29-38$.

37. Rodrigues EC, Farias BV, Adriano WS, Azevedo DCS, Gonçalves LRB, Silva Jr JS. Cinética e equilíbrio de adsorção de celulase de aspergillus niger em esferas de quitosana/alginato epoxiladas. Proceedings of XXXIV Congresso Brasileiro de Sistemas Particulados; 2009. Campinas, SP.

38. Schneider IAH, Rubio J, Misra M, Smith RW. Eichhornia Crassipes as biosorbent for heavy metal ions. Minerals Engineering. 1995; 8, 979-988. 
39. Skinner K, Wright N, Porter-Goff E. Mercury uptake and accumulation by four species of aquatic plants. Environmental Pollution. 2007; 145(1): 234-237.

40. Ghabbour EA, Davies G, Lam Y, Vozzella ME. Metal binding by humic acids isolated from water hyacinth plants (Eichhornia crassipes [Mart.] Solm-Laubach: Pontedericeae) in the Nile Delta, Egypt. Environmental Pollution. 2004; 131(3): 445-451.

Kamal M, Ghaly AE, Mahmoud N, Côté R. Phytoaccumulation of heavy metals by aquatic plants. Environment International. 2004; 29(8): 1029-1039.

2020 by the authors. Submitted for possible open access publication under the terms and conditions of the Creative Commons Attribution (CC BY NC) license (https://creativecommons.org/licenses/by-nc/4.0/). 